of religious life in Ukraine]. Filosofiia $i$ relihiia $v$ poshukakh dukhovnykh priorytetiv suchasnoho svitu: materialy misk. mizhvuz. seminaru. Kh.: KhNUBA. P. 153-155. (in Russian).

8. Relihiina samoidentyfikatsiia naselennia $i$ stavlennia do osnovnykh tse-rkov Ukrainy: cherven 2021 roku [Religious self-identification of the population and attitude to the main churches of Ukraine: June 2021.]. URL:

https://www.kiis.com.ua/?lang=ukr\&cat=reports\&id=1052 \&page $=1 \& \mathrm{t}=9$ (in Ukrainian).

9. Relihiia i tserkva v ukrainskomu suspilstvi: 20002020 rr. (sotsiolo-hichne doslidzhennia) [Religion and the church in Ukrainian society: 2000-2020 (sociological study)]. URL: https://razumkov.org.ua/uploads/ article/2020_religiya. pdf (in Ukrainian).

10. Rybachuk M. F. (1995). Natsionalne vidrodzhennia i relihiia [National revival and religion]. K.: Asotsiatsiia «Ukraino». 208 p. (in Ukrainian).

DOI: https://doi.org/10.17721/2520-2626/2021.29.20

UDC: 94:327.54 (4)“19”
11. Uhoda pro spivpratsiu mizh Ministerstvom osvity i nauky Ukrainy ta Vseukrainskoiu Radoiu Tserkov i relihiinykh orhanizatsii [Agreement on cooperation between the Ministry of Education and Science of Ukraine and the All-Ukrainian Council of Churches and Religious Organizations.].URL: https://sobor.com.ua/ news/spivpracya-mon-ta-vrciro. (in Ukrainian).

12. lakukhno I.I. Naukovo-metodolohichni ta praktychni problemy vzaiemodii Tserkvy u derzhavy $v$ sfery osvity [Scientific-methodological and practical problems of the Church's interaction with the state in the field of education.]. URL: https://www.zippo.net.ua/ index.php?page_id=134. (in Ukrainian).

\author{
Grygoriy Riy \\ Ph.D., Assistant Director of Analytical Center, \\ Chair of World History, \\ Faculty of History and Philosophy, \\ Borys Grinchenko Kyiv University,
}

ORCID: 0000-0002-1608-0960

Email: grygoriy.riy@gmail.com

\title{
REASONS FOR THE CREATION OF THE ANTI-BOLSHEVIK BLOC OF NATIONS (ABN): EASTERN EUROPEAN AND UKRAINIAN DIMENSIONS
}

\begin{abstract}
The article is devoted to a relatively poorly studied page in the history of the Ukrainian diaspora, the Anti-Bolshevik Bloc of Nations (ABN), an anti-communist organization of the period of the Cold War. The author identifies the reasons for the emergence and formation of the $A B N$, which restored its operation on April 16, 1946 in Munich. Later, almost 20 diaspora groups from Eastern Europe and Central Asia were merged into this structure. The author analyzes the reasons for the participation of Eastern European and Ukrainian diasporas in the formation of the bloc. In particular, the author analyzes the materials of already existing studies on various types of anti-communist movements. The article focuses on the fact that the Eastern European anti-communist movement represented by the $A B N$ was primarily anti-Bolshevik and differed from other anti-communist organizations, first of all, in the idea of establishing independent national states after the disintegration of the USSR.

Special attention is paid to the role of the Organization of Ukrainian Nationalists (Bandera) - OUN(B) in the creation of the concept of joint struggle of enslaved nations. Some other similar Eastern European projects and their cooperation with the $A B N$, in particular, the Polish emigrant organization "Prometheus" and representatives of the Russian "White" movement, are also considered. The research also emphasizes that the concept of joint struggle of subjugated nations against imperial rule, which emerged in Eastern Europe at the beginning of the $19^{\text {th }}$ century, lasted, respectively, until the $20^{\text {th }}$ century. At the beginning of the Cold War, when anti-communism became an integrative ideology of Western countries, the ABN, led by Yaroslav Stetsko, managed to establish contacts with representatives of Asian and Latin American anti-communist organizations. This allowed them to become part of a transnational anti-communist network. The stages of formation and entry of the ABN into the transnational anti-communist network are determined. Recent researches and publications on the outlined problem are analyzed. The author bases his study on unpublished documents and materials.
\end{abstract}


Keywords: Anti-communism, Nationalism, Fascism, Anti-Bolshevik Blok of Nations (ABN), the Cold War, the World Anti-Communist League (WACL).

Григоріŭ Рiŭ

доктор фрілософії в галузі «Гуманітарні науки», заступник директора Аналітичного центру, кафедра Всесвітньої історії, факультет історії та фрілософії,

Київський університет імені Бориса Грінченка

\title{
СТВОРЕННЯ АНТИБОЛЬШЕВИЦЬКОГО БЛОКУ НАРОДІВ (АБН): СХІДНОЄВРОПЕЙСЬКІ ТА УКРАЇНСЬКІ ЧИННИКИ
}

\begin{abstract}
Анотація. Стаття присвячена малодослідженій сторінці історії української діаспори, а саме появі антикомуністичної організації часів Холодної війни - Антибольшовицького Блоку Народів (АБН). У статті визначено причини формування неурядової організації АБН. АБН було утворено 16 квітня 1946 року в Мюнхені. Пізніше до загальної структури організації входило понад десяток емігрантських діаспорних груп зі Східної Європи та Середньої Азії. Автор аналізує східноєвропейські та українські причини, які сприяли формуванню блоку. Зокрема, у статті проаналізовано матеріали вже існуючих досліджень щодо різних типів антикомуністичних рухів. Стаття показує, що східноєвропейський антикомунізм репрезентований АБН мав насамперед антибільшовицьке спрямування та відрізнявся від інших антибільшовицьких рухів тим, що був направлений на створення незалежних національних держав на теренах СРСР.

Окрім того визначено роль Організації Українських Націоналістів (бандерівців) - ОУн(б) в фооруванні концепції спільної боротьби поневолених народів за утворення незалежних держав. Окреслено коло інших схожих східноєвропейських проєктів та їх співпрацю з АБН, зокрема із польською організацією «Прометей» та представниками російського білого руху в діаспорі. На початку Холодної війни, коли антикомунізм став інтегруючою ідеологією для Західних держав, керівництву АБН на чолі з Ярославом Стецьком вдалося встановити контакти з представниками азійських та латиноамериканських антикомуністичних організацій. Це дозволило їм стати складовою частиною транснаціональної антикомуністичної мережі. Визначено етапи фрормування та входження АБН до транснаціональної антикомуністичної мережі. Проаналізовано останні дослідження та публікації щодо окресленої проблеми. У статті використано документи і матеріали, які раніше не публікувалися.
\end{abstract}

Ключові слова: антикомунізм, націоналізм, фашизм, Антибольшевицький Блок Народів, Холодна війна, Світова Антикомуністична Ліга

\section{Introduction}

On the eve of the Cold war, anti-communism became an integrative ideology for Western countries. In March 1947, the President of the USA Harry S. Truman in his speech in Congress asked Americans to make a global commitment against communism [Ошибка! Источник ссылки не найден.]. After the communist coup in Czechoslovakia in 1948 and the blockade of West Berlin in 1948-1949, communism was seen as an existential threat for all democratic states. The world was divided into two opposite blocks: the Democratic (Free) world and the Communist world. Since then, different political groups (liberals, social democrats, Christian democrats, nationalists) in the Free world have united against communism. In this case, the French historian Jean-Francois Fayet pointed out seven types of anticommunism ideology: anti-communism of circumstance, anti-communism of indifference, anti-communism of denunciation, class-based anti-communism, anticommunism of the left, ideological anti-communism, and anti-communism of values. Becker suggested that anticommunism, like any other political ideology, could be incorporated into local cultures and even mixed with it, which is why he identified so many types of anticommunism. Fayet postulated that anti-communism has never been an expression of only one party, class, or philosophy [5].

But these types had more in common with Western but not Eastern European anti-communist representatives. Since 1945, there have been more than 4 million displaced persons in Germany, Austria, and Italy. In 1946, after the repatriation of most displaced persons, about 1.2 million DPs remained in Germany and Austria [15]. In general, almost all of them were from Eastern Europe, in particular, from the USSR. They lived in displaced person camps. Anna Holian, a historian, defined two opposing groups among the representatives of DP camps: federalist and separatist. The first one was mostly represented by former Tsar's officers (the socalled White emigration from the Russian empire), who struggled to transform the USSR into a new political unity - a federal democratic Russia that included all the territories of the former Russian empire. The second one was represented by their federalist opponents, whose main political goal was the disintegration of the USSR into independent national states [10]. The representtatives of the separatist groups were anti-Bolshevik rather than anti-communists because their enemy was not only communism as an ideology or political opposition, but also imperialism and national 
enslavement of the countries of Eastern Europe and Central Asia. They were united in the Anti-Bolshevik Bloc of Nations (ABN).

Although there are a plethora of studies on anticommunist activities during the Cold War, authors have only tentatively touched upon the history of the ABN. The available literature indicates that one of the most well-founded interpretations belonged to Stéphanie Roulin and Giles Scott-Smith [27]. They identified the $\mathrm{ABN}$ as one of the three largest anti-communist organizations, along with Asian anti-communist organizations and Latin American movements that existed during the Cold War. Additional information can be found in another work by Scott-Smith [29] as well as in the authoritative paper by Sosenko [31].

In contrast, Stefanie Birkholz, a German political scientist, argues that 'the central actors of the ABN could mainly look back at the past cooperation of Nazi and came from authoritarian and fascist movements and organizations of the interwar period' [4, 18-34].

One cannot but fully agree with such an interpretation. Birkholz followed the interpretation of $G$. Rossoliński-Liebe $^{7}$ [26] and J. P. Himka ${ }^{8}$ [Ошибка! Источник ссылки не найден.34] and wrote that 'a central element of the ideology of the OUN has been an ethnic understanding of the nation since its foundation... In addition, the OUN was radically anti-democratic, rejected parliamentarism, was anti-Semitic and anticommunist, while pretending to be anti-capitalist', [34, 414]. Shkrandriy, however, agrees with Motyl's argument concerning the difference between fascism and nationalism, according to which a fascist ideology can only develop when a national state already exists [1]. In addition, Zaitzev agrees with Motyl and Shkandriy and argues that the history of the OUN can be interpreted from a different designation - Ustashism [from the Croatian Ustaša] [Ошибка! Источник ссылки не найден.35].

In conclusion, when we talk about the Eastern European anti-Bolshevik movement, we must agree that, although they cooperated in some ways with the Nazis, they did so because they were struggling against the Communists to establish their national states. First of all, they were anti-colonial national movements, which were needed for political support to destroy Versal's international system. At that time, Germany was the main revisionist force in Europe. But cooperation did not mean that you became Nazis or fascists just because of

${ }^{7}$ In Rossoliński-Liebe's opinion the 'liberation struggle' or 'liberation war' practiced by the OUN and UPA could not have been liberation because it was not necessary to kill several thousand civilians to liberate Ukraine"

8 Historian John-Paul Himka's approach is more consistent, as he does not consider the national liberationist nature of the movement to be an obstacle to recognizing it as fascist. some agreements, and the creation of an alliance with the USSR did not mean that American Democrats or British Conservatives became communists because they both cooperated and fought against German Nazis and Italian fascists.

Such cases of temporary cooperation during the World War II were reported in Western Ukraine, Belarus, Lithuania, Estonia, and Latvia. They were representatives of national movements from the USSR, whose main goal was the disintegration of the communist regimes. They were able to be 'chameleons' precisely because their ideology is fundamentally indifferent to the type of regime, political system or state that emerges in the newly created state [7]. It was a principle of Realpolitik. The official documents of the OUN indicated that the OUN's attitude toward other states and political movements depends on their antiBolshevik orientation [7]. After 1945, representatives of other newly-Soviet states of Eastern Europe, such as Croatis, Hungarians, Czechs, Slovaks, and others became strongly anti-communist.

1943: anti-imperialist and anti-Bolshevik reasons

The ABN was formed under the final resolution of the first conference of enslaved nations. In late autumn 1943, the First Conference of Oppressed Nations was convened through the initiative of the Ukrainian underground liberation movement that was fighting against both the Russian Red Army and the Nazi Wehrmacht in Polesia. Participants represented 13 nationalities; Ukrainian (5 delegates), Belarusian (2), Georgian (5), Azerbaijani (6), Armenian (4), Tatar (2), Ossetian (2), Kabardian (1), Circassian (1), Bashkir (1), Chuvash (1), Uzbek (5), and Qazaq (1) [2, 30-37]; and resolved to establish a National Committee of Enslaved Nations for further coordination of the revolutionary liberation struggle.

What made it possible to hold such an ambitious conference during the "hot" phase of World War II on the Eastern Front? Several specific statements could be made.

First of all, it is the presence of multimillion and multinational armed formations, such as the Nazi Wehrmacht and the Communist Red Army. They were built on an ideological basis and the cult of personality. Both the Germans and the Soviets crossed the territory of Eastern Europe twice, which allowed for a large number of desertions, especially among soldiers, who represented other nations and did not identify themselves with the Russians or the Germans. Sometimes they were far from their homelands, did not want to continue fighting, deserted to the resistance movements.

For example, in the summer of 1943 on the territory of Volhynia (now in the western part of Ukraine), which was controlled by the Ukrainian Insurgent Army (UPA), Roman Petrenko, Head of the UPA's external relations department, wrote that during his trip across 
controlled areas he met Hungarians, Lithuanians, Germans, some representatives of Central Asian nations, who deserted from the Wehrmacht, such as, Uzbeks, Qazaqs, Tajiks, Turkmens and others [22, 159172]. Usually, these were single cases of desertion without any organized form. In the UPA, they were organized into small national armed groups. Later, when the Red Army closed in Volhynia, the cases of desertion highly increased. In the autumn of 1943, there were almost a hundred Russians among the UPA's armed forces, who represented themselves as Ukrainians, Belarusians, Cossacks from Kuban or Don.

Why did all of them join the UPA? First of all, because they needed security. The Communist Resistance Movement, Polish Armia Krajowa and different Ukrainian movements operated in the territories of Volhynia and Polesia in the autumn of 1943. Besides, the center of the Nazi occupation administration was situated in Rivne, Volyn. Secondly, on the eve of the WWII, future UPA commanders took part in a mass propaganda campaign, the main aim of which was to arouse national feelings among the peoples of the USSR. This campaign was part of the concept of the joint struggle of subjugated nations against the Bolsheviks.

The above-mentioned concept was the product of the intellectual work of the OUN members. In 1929, some Ukrainian organizations, such as the Ukrainian Military Organization, which united former Ukrainian soldiers and veterans of the Ukrainian War of Independence, gathered in Vienna for the First Congress of Ukrainian Nationalists, where the Organisation of Ukrainian Nationalists (OUN) was founded. Yevhen Konovalets, a former military commander of the Ukrainian People's Republic (UNR) army, was elected as leader of the OUN.

The concept of the struggle of subjugated nations was formulated and articulated in the OUN in the late 1930s. The idea of a joint struggle of enslaved peoples appeared in the OUN literature in August 1939, when the Roman Grand Assembly decided:

"The Great Assembly of Ukrainian Nationalists calls on all captive peoples of Ukraine, fighting for their liberation, to cooperate with the OUN" [33].

Then, in December 1940, the Manifesto proclaimed the ultimate goal not only of the OUN struggle, but also of the struggle of enslaved nations- to gain "freedom for the peoples and man" $[21,21]$.

Following the split in the organization in February 1940 , both factions continued to support the idea of joint struggle. The resolutions of the Second Grand Assembly of the OUN (S. Bandera - OUN-B), convened in 1941, stated:

"...the OUN is fighting for the freedom of all the peoples enslaved by Moscow and their right to create own state..." $[32,11]$.

Therefore, since 1940, the idea of a 'joint struggle' has constantly appeared in the documents of the OUN-B, and later traced in the appeals of the Ukrainian Insurgent Army (UPA). So much so that there was a special propaganda campaign for enslaved nations to spread this idea.

As mentioned earlier, in late autumn 1943, the First Conference of Enslaved Nations was held upon the initiative of the OUN-B and the UPA. Participants of the conference agreed to cooperate in the Committee of Enslaved Nations and:

"organize National Rebels of the Army, withdraw members of their nationalities from the Red Army, organize national-political forces on their territories and on Ukrainian territory, where many members of enslaved peoples are located" [32, 78].

Crucial to cooperation with other national movements was their attitude toward an independent Ukrainian state within its ethnic borders. The restoration of Ukrainian Statehood was placed by the OUN-B members in first place along with the joint struggle with other non-state nations:

"At the same time, Ukraine, as the bearer of progressive ideas among all enslaved peoples, becomes a decisive factor in the preparation of revolutions in the East" [32, 86].

And lastly, the First Conference of Enslaved Nations would not have been possible without the previously existing related projects in Eastern Europe and the process of disintegration of the Russian and Austria-Hungarian Empires. Thus, the idea of a joint struggle against imperial rule was not new. The first such meeting, in Prague in 1848 gathered representatives of the Czech, Slovak, Ukrainian, Polish, Serbian, Croatian, Montenegrin, and Russian communities. They aimed to transform the Habsburg Empire into a federal union based on the cooperation and amalgamation of the Austrian Slavs under the principle of securing national rights. However, the goal was not achieved, because the dominant trend of the era was differentiation, rather than integration of forces under the auspices of the Slavic ideal [24].

In the Russian Empire, the tendency to jointly solve the problem of nationalities appeared later, in the period of the "empire decay" [16]. National movements in the Russian Empire developed with varying intensity. Even after the overthrow of autocracy in February 1917, the idea of a federation remained. For example, in Kyiv, the Ukrainian Central Council convened a Congress from the 21st - 28th September 1917 to find ways to transform the former Russian Empire into a federal system [25, 7]. The Congress was attended by represent-tatives of the Tatar, Georgian, Latvian, Jewish, Belarusian, Estonian, Moldavian, Don Cossack, Union of Cossack troops, and Buryat societies.

Mykhailo Hrushevsky, leader of the Ukrainian national movement in 1917, wrote in 1907 that "... without transforming Russia into a free union of peoples, its complete renewal of the grim remnants of the past is unthinkable" [11, 111]. Unfortunately, national interests 
were stronger than common aspirations [12, 273], and the resolution of the Congress failed to be achieved. Instead, most Eastern European nations proclaimed their independence after the First World War. As noted by A. J. Motyl, the Austro-Hungarian Empire underwent profound reconstruction as such, and state power was more evenly balanced between the center and the periphery. Whereas in Russia, the empire suffered minimal destruction, which created the necessary conditions to allow the empire to revive, but with ideological change. Therefore, the Soviet Union can be considered a reincarnation of the former Russian Empire [13].

A. Rusnachenko concurred with Motyl's thesis and asserted that "...the desire to embody the imperial idea, in this case the communist one, through constant expansion. The last, like all other empires, was the ideal goal of the state" [14]. Similarly, the idea of national movements continued to exist in the Soviet Empire. Consequently, in the mid-1930s, through the use of terror and repression against elites, peasants, clerics, and others, the Communist regime attempted to resolve the problem of national movements in the most terrible of ways.

The newly formed Eastern European states of Poland, Romania, and Czechoslovakia viewed the Soviet Union as a threat. During the 1920s, their respective governments attempted to establish a 'Union of Defense' by signing a series of agreements. In August 1920 , one such pact was signed in Belgrade between Czechoslovakia and the Kingdom of Serbs, Croats and Slovenes. In 1921, Czechoslovakia concluded a similar treaty with Romania, and later with the Kingdom of Serbs, Croats and Slovenes.

However, an alternative political project known as Prometeism (or Prometheism) has been developed in Poland. The policy was named after Prometheus, the titan who gave Pandora a secret box. In my opinion, Prometheism can be said to have been one of the first anti-communist movements in Eastern Europe. Its aim was the destruction of the Soviet Union and the proclamation of national states within the former Soviet republic. Accordingly, the Polish government attempted to support national movements within the Soviet Union covertly. For example, they called upon Ukrainians to draw their own conclusions from cultural progress - in the sense of the Ukrainization policy - to establish an independence movement [30, 39].

The first such 'Promethean' organization was the "Union of Revived Nations", created in 1921 in Warsaw and united into a single entity, an emigrant from the former Tsarist Russia [13, 118]. The concept as a whole was aimed at securing Poland's interests. Józef Pilsudski initiated the strategy and, upon his return to power in 1926, the budget of the Prometheism project increased (nine thousand zloty in 1927 to $1,450,000$ in 1932) $[30,41]$.

To summarize, the concept of joint struggle of the subjugated nations against imperial rule, which emerged in Eastern Europe at the beginning of the $19^{\text {th }}$ century lasted, accordingly, until the $20^{\text {th }}$ century. As noted by Motyl, the USSR was typical of an empire, and, as such, there were national movements that did not recognize its borders, nor its quasi-national republics. Such movements were partially (and secretly) supported by the Polish and Japanese governments during the interwar periods. After failing to achieve its objectives in the National Struggle of 1917-21, the Ukrainian national movement was almost completely suppressed by the Communist regime, but thanks to its emigrant population, notably in Poland, the movement was able to restore its power. Within the Polish state, the Ukrainian national movement was represented in both legal and illegal forms. The failure of the legitimate Ukrainian political party to make concessions to the Polish authorities resulted in the establishment of illegal formations, firstly, the UMO and then the OUN. Thus, it can be argued that since its inception, the OUN has fought against both Polish and Soviet oppressors.

Despite the disparate attitudes of historians towards the ideology of the OUN, this paper attempts to highlight that among the membership the concept of a joint struggle with other enslaved nations was successively developed and realized by the UPA commanders at the First Conference of Enslaved Nations in autumn 1943. Implementation of this concept was consistent throughout the Second World War and subsequent years.

1946: early Cold War reasons

On the $16^{\text {th }}$ of April 1946, an organization called the Anti-Bolshevik Bloc of Nations (ABN) was formed in the American Zone of Occupation in Munich. The main aim of the $A B N$, following the proclamation, was:

"the destruction of the Bolshevik regime and the reconstruction of the national states of their peoples, ... the struggle against Bolshevism and any other form of Russian imperialism...Our main aim is to fight Bolshevism in our own countries. It is only the foreign committee of the $A B N$ that exists abroad, the greater part of our work is done in our native countries" [6].

Furthermore, members proclaimed that the $A B N$ was against:

"... totalitarianism of all kinds, imperialism and militarism, national enslavement, socio-economic relations that allow human exploitation, spiritual and cultural oppression, terror..." [2, 30-37].

Fourteen national organizations, representing mostly Eastern European, but also Asian emigrant groups, came together to form one union. The ABN members represented the following nationalities: Estonians, Latvians, Lithuanians, White Ruthenians, Czechs, Slovaks, Hungarians, Serbs, Croats, Albanians, Bulgarians, Romanians, Ukrainians, Qazaqs, North Caucasians, Georgians, Turkmens and Azerbaijanis, Armenians, Tatars, the peoples of Idel-Ural and Siberia.

How did they all unite in the ABN? First, as shown above, the UPA had a strong tie with other 
national movements during the Second World War. Second, the Nazis were interested in cooperation with representatives of subjugated nations at the end of the war. They were seen as a kind of buoy that would help not to fail in the war. There were developed two strategies to build such cooperation: 1) mobilization of all representatives around the Russian army of General Vlasov, which was formed as the de jure army of the Committee for the Liberation of the Peoples of Russia, but was de facto a military unit of the Wermacht; 2) to build on equal rights the national committee for Eastern Europeans with national military formations [2, 439].

The Nazi commanders chose the first strategy. In the autumn of 1944, they released the leaders of national movements, who had been imprisoned at the beginning of the war. Among them were Yaroslav Stetsko, a former Ukrainian prime minister, who proclaimed the restoration of Ukrainian independence on June 30, 1941 in Lviv, on the eve of the Nazi capture of the city, and one of the leaders of the $\operatorname{OUN}(b)$, who was imprisoned after he refused to withdraw the proclamation. After the war, Stetsko was responsible for the international policy of the OUN(B). Stepan Bandera, the $\operatorname{OUN}(B)$ leader, as well as Andriy Melnyk, the leader of the opposing fraction OUN(M) were also released [23, 56]. The Nazis hoped that they would agree to cooperate and create the Ukrainian National Committee. But they both refused and fled to the American occupational zone $[14,452]$.

Third, the future members of the $A B N$ were mostly former DP's persons. The newly-organized Foreign Units of the OUN (or ZCH OUN from Zakordonni chastyny OUN) disseminated appeals, proclamations and another type among nations in the DP camps. There was a kind of propaganda campaign to restore national and anti-Bolshevik feelings.

As a result, in 1946 the ABN was established. Their first major international event was the Memorandum to the Peace Conference of the Foreign Ministers in Paris. The ABN members sought to persuade Western states and newly formed international organizations, such as the United Nations, to exert constant pressure on the USSR and its satellites. They also wanted to recognize full respect for the principle of the right to self-determination, which, due to persistent violations or favorable redistribution between influential countries, could not be respected in Eastern Europe. The main aim of the Memorandum was to convince the foreign ministers of Western governments to create a new political order in Eastern Europe, based on the principle of selfdetermination [2, 38] and recognition of the émigré political groups as a government in exile. They even appealed to the UN, which, in their opinion, might include representatives of national movements [2, 119].

"Continuing to recognize the Bolshevik regime means recognizing totalitarianism and rejecting the common goals and ideals of democracy, recognizing military aggression and violence against the rights of peoples to self-determination as a means of building international relations" [2, 45] - the authors of the Memorandum stated.

The $A B N$ members did not receive any reaction to their Memorandum. On April 10, 1949, the ABN organized the first public demonstration in Munich. There were from 3 to 10 thousand participants. The theme of the meeting was the suppression of national selfdetermination in the USSR. The demonstration was stopped in about an hour by the police that applied tear gas and bayonets to people. The police did this, because demonstrators changed the way of the event schedule. The speeches provoked a demonstration at the office of the Soviet mission in Munich, which was not part of the previously agreed plan [10]. The ABN Press Office later stated that the demonstration was spontaneous, provoked by the German Communists. The demonstration did not yield the desired results and the $A B N$ did not receive broad support among the Germans [2, 153-158].

But public anticommunism gave something else some kind of political support among the Germans Christian Democrats, who were popular among Bavarians. Later, ties with European conservative circles allowed the $A B N$ to become part of the transnational anti-Communist network.

CIA documents revealed that the $\mathrm{ABN}$, through its contacts with the German Christian Democrats, was able to attend the fifth meeting of the European Centre for Documentation and Information in Madrid [8], resulting in the opening of a Spanish branch and an official office [9].

The second phase was initiated by the Catholic Archbishop of Nanjing, Paul Yu, who was impressed that the ABN had such support among Catholics [35]. The result was a collaboration between the $A B N$ and Asian anti-communists. Yu attempted to support, in every way possible, the Taiwanese in their struggle against Communist China. It is highly probable that because the ABN had strong support from influential Christian political parties in Europe, Yu agreed to assist them. In 1957, the ABN mission was opened in Taipei [3, 54-58].

"There is considerable sympathy among the Chinese for the $A B N$ because, among several reasons, the Chinese and the $A B N$ use identical slogans, summed up in 'Oppose Communism, Resist Russia'" [9] - states the CIA document.

Simultaneously, the ABN attempted to enter into close relations with the Inter-American Confederation for the Defense of the Continent and the Anti-Communist Popular Front. Yaroslav Stetsko invited their leaders to Munich, where the ABN headquarters was located. On the $18^{\text {th }}$ of September 1957, Admiral Carlos Penna Botto (Brazil) and Jorge Prieto Lawrence (Mexico) arrived in Germany. The main purpose of the meeting was to discern common ways and plans for further cooperation in the struggle [3, 54-58]. 
Of particular relevance was the creation of a united anti-communist organization, but it was not until 1967 that the first Conference of the World AntiCommunist League was held.

\section{Conclusion}

The Anti-Bolshevik Bloc of Nations was an integral part of the transnational anti-communist network. The ABN's involvement and cooperation with representatives of other anti-communist movements can be distinguished through several key steps. The first stage was the unification of emigrant organizations around anti-communist ideas in Eastern Europe, 19461954. The second stage was the establishment of ties with Asian and Latin American anti-communist organizations in the mid-1950s. The third element was the formation of the World Anti-Communist League (WACL) in the mid-1960s, and, last but not least, was the ABN's activity within both the WACL and the European Freedom Council until the 1990s.

There is no denying that the $A B N$ was the product of the ideological thoughts of the Organization of Ukrainian Nationalists, which was established in 1929. Nevertheless, upon discussing the OUN ideology, there is no doubt that it has been anti-communist since its inception. Its members developed the notion of a joint struggle amongst all enslaved nations in the USSR in the 1930s, and after World War II it extended its ideals among other Eastern European movements. Of course, there were other similar associations, such as the Promethean Atlantic Charter League and the International Movement for Liberty OUN-M, which attempted to create a joint organization called the AntiBolshevik League for the Liberation of Nations (in Ukrainian: Antybil'shovyts'ka liha vyzvolennya narodiv, АЛОН), but it was not successful.

Thus, the $A B N$ was the most influential anticommunist organization in Eastern Europe. It was not only the largest anti-Soviet underground movement in Ukraine, but also one of the largest in Eastern Europe that supported the anti-communist network and its goals.

“... Ukrainians are not only supporters of the ideas of the $A B N$, but they are also its practical implementers, including in the liberation struggle of other peoples based on mutual assistance and cooperation" [21, 199].

Therefore, there is no doubt that the OUN-B was one of the main representatives of the Ukrainian national movement after the war. Their use of anti-communist ideas puts the Ukrainian national movement at the forefront of the fight against the Soviet empire.

1. A roundtable on Myroslav Shkandrij's "Ukrainian nationalism: politics, ideology, and literature, 1929-1956”. Canadian Slavonic Papers, 2017, 59(1-2), pp.131-152.

2. Антибольшевицький Блок Народів в світлі постанов Конференцій та інших матеріялів 3 діяльности 1941-1956 рp. (збірка документів).
Видання Закордонних Частин Організації Українських Націоналістів, 1956. 357 р.

3. Антибольшевицький Блок Народів в світлі постанов Конференцій та інших матеріялів з діяльности 1941-1956 рр. (збірка документів). Частина 2. 1979. Мюнхен: Видання Закордонних Частин Організації Українських Націоналістів. 462 с.

4. Birkholz, S. Die stärksten verbündetendes westens. Der antibolschewistische block der nationen 1946-1996. 2017. Hamburg: KVV konkret. 143 s.

5. Fayet, J. A century of anti-communisms: a roundtable discussion. Twentieth Century Communism, 2014, 1(6).

6. Fight of the $A B N$ for the freedom of peoples and the freedom of the individual. $A B N$ Correspondence, 1950, №1, p.1.

7. Форум, Україна модерна, 2014, №20. URL: https://uamoderna.com/arkhiv/um-2013-20.

8. Freedom of information act electronic reading room, Central Intelligence Agency - CIA. URL: https://www.cia.gov/library/readingroom/docs/STETSKO, \%20YAROSLAV_0082.pdf.

9. Freedom of information act electronic reading room, Central Intelligence Agency - CIA. URL: https://www.cia.gov/library/readingroom/docs/STETSKO \%2C\%20YAROSLAV_0074.pdf

10. Holian A. Anticommunism in the streets: refugee politics in Cold war Germany. Journal of Contemporary History, 2010, 45(1), pp.134-161.

11. Грушевский, Михаил Сергеевич. Освобождение России и украинский вопрос: статьи и заметки / Мих. Грушевский. СПб., 1907. URL: http://elib.shpl.ru/ru/nodes/16548-grushevskiy-m-sosvobozhdenie-rossii-i-ukrainskiy-vopros-stati-i-zametkispb-1907

12. Каппелер А. Росія як поліетнічна імперія: виникнення, історія, розпад. - Львів: Вид-во Католицького Українського університету, 2005. 360с.

13. Комар В. Л. Конценція прометеїзму в політиці Польщі (1921-1939рр.): монографрія. ІваноФранківськ: Місто НВ, 2011. 360 с.

14. Косик В. Україна і Німеччина у Другій світовій війні. Париж; Нью-Йорк; Львів: 1993. 658 с.

15. Markus V. Displaced Persons. URL: http://www.encyclopediaofukraine.com/display.asp?linkp ath=pages $\backslash D \backslash I \backslash D i s p l a c e d p e r s o n s . h t m$.

16. Motyl A. Imperial Ends: The Decline, Collapse, and Revival of Empires. Columbia University Press, 2001. $128 \mathrm{p}$.

17. Motyl A. The Ukrainian Nationalist Movement and the Jews: Theoretical Reflections on Nationalism, Fascism, Rationality, Primordialism, and History. POLIN: Jews and Ukrainians, 2014, №26, pp. 275-295.

18. Motyl A. Putin's Russia as a Fascist Political System. Communist and Post-Communist Studies, 2014, Vol.49, Issue 1, pp. 25-36.

19. Nationalism.

URL: https://www.oxfordreference.com/view/10.1093/acref/97 80199599868.001.0001/acref-9780199599868-e1243 ?rskey=sxxc0G\&amp;result=1229. 
20. Nazis and axis collaborators were used to further U.S. anti-communist objectives in Europe--some immigrated to the united states. U.S. Government Accountability Office (U.S. GAO), 1985.

21. ОУН в світлі постанов Великих Зборів, Конференцій та інших документів з боротьби 19291955 рр. Збірник документів. Мюнхен, 1955, 371 с.

22. Петренко Р. За Україну, за її волю: спогади / за ред. Г. Петренко. - Львів ; Торонто : Літопис УПА, 1997. 277 с. (Літопис Української Повстанської Армії ; т. 27)

23. Посівнич М., Брелюс В. Нарис життя Дарії Ребет - “Орлян". (Серія «Події і люди». Кн. 26). Торонто - Львів: В-во «Літопис УПА», 2013. 112 с.

24. Райківський І. Питання єдності руськоукраїнського простору в громадській думці Галичини під час революції 1848-1849 рр. / І. Райківський . Галичина. 2013. Ч. 22-23. С. 159-168. URL: http://www.irbis-nbuv.gov.ua/cgi-

bin/irbis_nbuv/cgiirbis_64.exe?I21DBN=LINK\&P21DBN= UJRN\&Z21ID $=\& S 21 R E F=10 \& S 21 C N R=20 \& S 21 S T N=1$ \&S21FMT=ASP_meta\&C21COM=S\&2_S21P03=FILA= \&2_S21STR=Nikp_2013_22-23_19

25. Реєнт О. П., Андрусишин Б. І. З'їзд поневолених народів (8-15 вересня 1917 р.) / АН України. Інститут історії України. К., 1994. 72 с.

26. Rossoliński-Liebe G. Stepan Bandera. The Life and Afterlife of Ukrainian Nationalist. Stuttgart, 2015. $670 \mathrm{p}$.

27. Roulin, S., Scott-Smith G. Transnational AntiCommunism and the Cold War. Palgrave Macmillan UK, 2014. $292 \mathrm{p}$.

28. Імперія (ï) і національно-визвольні рухи в Центральній і Східній Європі від середини XX століття / А. Русначенко. Український визвольний рух: наук. зб. Львів, 2005. Збірник 4. С. 35-42. URL: http://shron1.chtyvo.org.ua/Rusnachenko_Anatolii/Imperi ia_i_i_natsionalno-

vyzvolni_rukhy_v_Tsentralnii_i_Skhidnii_Yevropi_vid_se redyny_XX_stolittia.pdf.

29. Scott-Smith, G. Western Anti-Communism and the Interdoc Network: Cold War Internationale. Palgrave Macmillan UK, 2012. 388 p.

30. Snyder, T. Sketches from a Secret War: A Polish Artist's Mission to Liberate Soviet Ukraine, New Haven and London, 2015. 347 p.

31. Sosenko, A. Eastern European Unity Under Russian Communism and the Anti-Bolshevik Bloc of Nations: Conception, Ideology, and Conferences. M.A., University of Illinois at Urbana-Champaign, 2010. URL: http://citeseerx.ist.psu.edu/viewdoc/download?doi=10.1. 1.205.409\&amp;rep=rep1\&amp;type=pdf.

32. Українська суспільно-політична думка в 20 столітті : док. і матеріяли / упоряд.: Т. Гунчак, Р. Сольчаник. Сучасність, 1983. Т. 3. 1983. 381 с.

33. Відозва II-го Великого Збору Українських Націоналістів (Серпень 1939 р.). URL: https://web.archive.org/web/20120711021540/http://ounupa.org.ua/documents/oun03.html
34. Zaitsev O. De-Mythologizing Bandera: Towards a Scholarly History of the Ukrainian Nationalist Movement. Journal of Soviet and Post-Soviet Politics and Society, 2015 Vol.1, Issue 2, pp. 411-420.

35. Zaitsev O. Fascism or ustashism? Ukrainian integral nationalism of the 1920s -1930s in comparative perspective. Communist and post-communist studies, 2015, Vol.48, pp.183-193.

\section{Reference}

1. A roundtable on Myroslav Shkandrij's "Ukrainian nationalism: politics, ideology, and literature, 1929-1956”. (2017). Canadian Slavonic Papers. 13152.

2. Antybil'shevyts'kyy Bl'ok Narodiv: zbirka dokumentiv 1941-1956 rr (1956). [Anti-Bolshevik Bloc of Nations: a collection of documents of 1941-1956]. 357 p. (in Ukrainian).

3. Antybil'shevyts'kyy Bl'ok Narodiv: zbirka dokumentiv 1956-1966 rr. (1979). [Anti-Bolshevik Bloc of Nations: a collection of documents of 1941-1956].]. Vol. 2. Munich. 462 p. (in Ukrainian).

4. Birkholz, S. (2017). Die stärksten verbündetendes westens. Der antibolschewistische block der nationen 1946-1996. Hamburg: KVV konkret. (in German).

5. Fayet, J. (2014). A century of anticommunisms: a roundtable discussion. Twentieth Century Communism. (6).

6. Fight of the $A B N$ for the freedom of peoples and the freedom of the individual. (1950). $A B N$ Correspondence. (1), 1.

7. Forum. (2014). Ukraina Moderna 20. URL: https://uamoderna.com/arkhiv/um-2013-20. (in Ukrainian).

8. Freedom of information act electronic reading room | CIA FOIA (foia.cia.gov) Central Intelligence Agency - $\quad$ CIA. URL: https://www.cia.gov/library/readingroom/docs/STETSKO, \%20YAROSLAV_0082.pdf. (in English).

9. Freedom of information act electronic reading room | CIA FOIA (foia.cia.gov) Central Intelligence Agency - $\quad$ CIA. URL: https://www.cia.gov/library/readingroom/docs/STETSKO \%2C\%20YAROSLAV_0074.pdf (in English).

10. Holian, A., (2010). Anticommunism in the streets: refugee politics in Cold war Germany. Journal of Contemporary History. 45(1), 134-61.

11. Hrushevs'kyy M. (1907). Osvobozhdenye Rossyy y ukraynskyy vopros [Liberation of Russia and the Ukrainian question]. СПб, URL: http://elib.shpl.ru/ru/nodes/16548-grushevskiy-m-sosvobozhdenie-rossii-i-ukrainskiy-vopros-stati-i-zametkispb-1907 (in Russian).

12. Kappeler A. (2005). Rosiya yak polietnichna imperiya: Vynyknennya. Istoriya. Rozpad. [Russia as a polyethnic empire: Origin. History. Decay]. Lviv: Vydavnytstvo UKU. 360 p. (in Ukrainian).

13. Komar V. (2011). Kontseptsiya prometeyizmu v politytsi Pol'shchi (1921-1939). [The concept of 
Prometheanism in Polish politics (1921-1939)]. IvanoFrankivs'k: Misto NV. 360 p. (in Ukrainian).

14. Kosyk V. (1993). Ukraina I Nimechchyna $v$ Druhii Svitovii Viini [Ukraine and Germany in World War II]. Paris-New-York-Lviv: Atlas. 658 p. (in Ukrainian).

15. Markus V. (1984). "Displaced Persons". Internet

Encyclopedia of Ukraine. URL: http://www.encyclopediaofukraine.com/display.asp?linkp ath=pages $\backslash D \backslash I D$ isplacedpersons.$h t m$

16. Motyl A. (2001). Imperial Ends: The Decline, Collapse, and Revival of Empires. Columbia University Press. $128 \mathrm{p}$.

17. Motyl A. (2014). The Ukrainian Nationalist Movement and the Jews: Theoretical Reflections on Nationalism, Fascism, Rationality, Primordialism, and History. POLIN: Jews and Ukrainians 26:275-95.

18. Motyl A. (2016). Putin's Russia as a Fascist Political System. Communist and Post-Communist Studies 49, № 1: 25-36. URL: https://doi.org/10.1016/j.postcomstud.2016.01.002.

19. Nationalism. Oxford Reference. URL: https://www.oxfordreference.com/view/10.1093/acref/97 80199599868.001.0001/acref-9780199599868-e1243 ? rskey=sxxc0G\&amp;result=1229

20. Nazis and axis collaborators were used to further U.S. anti-communist objectives in Europe--some immigrated to the united states, (1985). U.S. Government Accountability Office (U.S. GAO)

21. OUN u svitli postanov Velykykh Zboriv I Konferentsiy ta inshykh dokumentiv z borot'by (1929-55 $r r) .91955$.$) . [The OUN in the light of the resolutions of$ the Great Assembly, Conferences and other documents on the struggle of 1929-1955.]. Munich. 371 p. (in Ukrainian).

22. Petrenko R. (1997). «Za Ukrainu, Za Yii Voliu» (Spohady) [For Ukraine, for its freedom (memories)]. Vydavnytstvo Litopys UPA. 279 p. (in Ukrainian).

23. Posivnych M., Brelus V. (2013). Narys Zhyttia Darii Rebet - «Orlyan» [Essay on the life of Daria Rebet - «Orlyan».] Toronto: Vydavnytstvo «Litopys UPA». 110 p. (in Ukrainian).

24. Raikivsky I. (2013). Pytannya yednosti rus'koukrayins'koho prostoru $v$ hromasl'kiy dumtsi Halychyny pid chas revolyutsiyi 1848-1849 rr. (Do 165-yi richnytsi yevropeys'koyi "vesny narodiv" 1848 r. u Halychyni) [ The question of the unity of the Russian-Ukrainian space in the public opinion of Galicia during the revolution of 1848-1849 (To the 165th anniversary of the European "Spring of Nations" in 1848 in Galicia)]. URL: http://irbisnbuv.gov.ua/cgi-

bin/irbis64r_81/cgiirbis_64.exe?C21COM=2\&amp;I21DB $\mathrm{N}=U J R N \& a m p ; P 21 D B N=U J R N \& a m p ; Z 21 I D=$ \&amp;IMA GE_FILE_DOWNLOAD=1\&amp;Image_file_name=PDF/ Nikp_2013_22-23_19.pdf. (in Ukrainian).
25. Reyent O., Andrusyshyn B. (1994). Zyizd ponevolenykh narodiv (21-28 veresnya 1917 r.). [Congress of Enslaved Peoples (September 21-28, 1917)]. Kyiv: Istorychni zoshyty / NAN Ukrayiny, Instytut istoriyi (in Ukrainian).

26. Rossoliński-Liebe G. (2015). Stepan Bandera. The Life and Afterlife of Ukrainian Nationalist. Stuttgart. $670 \mathrm{p}$

27. Roulin S., Scott-Smith G. (2014). Transnational Anti-Communism and the Cold War. Palgrave Macmillan UK. 292 p.

28. Rusnachenko A. (2005). Imperiya(yi) i natsional'no-vyzvol'nirukhy $v$ Tsentral'niy $i$ Skhidniy Yevropi vid seredyny $X X$ stolittya [Empire (s) and national liberation movements in Central and Eastern Europe from the middle of the twentieth century]. URL: http://shron1.chtyvo.org.ua/Rusnachenko_Anatolii/Imperi ia_i_i_natsionalno-

vyzvolni_rukhy_v_Tsentralnii_i_Skhidnii_Yevropi_vid_se

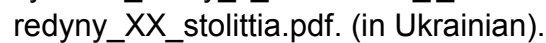

29. Scott-Smith G. (2012). Western AntiCommunism and the Interdoc Network: Cold War Internationale. Palgrave Macmillan UK. 388 p.

30. Snyder T. (2015). Sketches from a Secret War: A Polish Artist's Mission to Liberate Soviet Ukraine, New Haven and London. 347 p.

31. Sosenko A. (2010). Eastern European Unity Under Russian Communism and the Anti-Bolshevik Bloc of Nations: Conception, Ideology, and Conferences. M.A., University of Illinois at Urbana-Champaign. URL: http://citeseerx.ist.psu.edu/viewdoc/download?doi=10.1. 1.205.409\&amp;rep=rep1\&amp;type=pdf.

32. Ukrayins'ka suspil'no-politychna dumka v 20 stolitti. (1983) [Ukrainian socio-political thought in the twentieth century]. 3d volume. New York: Suchasnist'. 381 p. (in Ukrainian).

33. Vidozva II-ho Velykoho Zboru Ukrayins'kykh Natsionalistiv (Serpen' 1939 r.). [Recall of the Second Grand Assembly of Ukrainian Nationalists (August 1939)]. URL: https://web.archive.org/web/20120711021540/http://ounupa.org.ua/documents/oun03.html (in Ukrainian)

34. Zaitsev O. (2015). De-Mythologizing Bandera: Towards a Scholarly History of the Ukrainian Nationalist Movement. Journal of Soviet and Post-Soviet Politics and Society, 1(2): 411-20.

35. Zaitsev O. (2015). Fascism or ustashism? Ukrainian integral nationalism of the 1920s -1930s in comparative perspective. Communist and postcommunist studies, 48:183-93. 